\title{
A systematic review of published literature describing factors associated with tuberculosis recurrence in people living with HIV in Africa
}

\author{
Yoshan Moodley, Kumeren Govender
}

Nelson R. Mandela School of Medicine, University of KwaZulu-Natal, Durban, South Africa.

\begin{abstract}
Background: A summary of factors associated with recurrent tuberculosis (TB) in the African HIV-infected population is lacking. We performed a systematic review to address this.

Methods: We performed a literature search within PubMed and The WHO Global Library with specific inclusion and exclusion criteria to identify manuscripts emanating from the African continent which potentially described factors associated with recurrent TB in persons living with HIV.

Results: The literature search yielded 52 unique manuscripts, of which only 4 manuscripts were included in the final systematic review following application of the inclusion and exclusion criteria. Baseline CD4 count, baseline HIV viral load, a positive tuberculin skin test, prior active TB disease, cutaneous hypersensitivity reaction to treatment, having $<3$ lung zones affected by prior TB disease, and anaemia were associated with recurrent TB in HIV-infected individuals, whilst age and antiretroviral status were not.

Conclusion: The lack of studies describing recurrent TB in Africa which stratify results by HIV-status is a hindrance to understanding risk factors for recurrent TB in this population. This might be overcome by implementing guidelines related to the publishing of data from observational studies in peer-reviewed medical journals reporting recurrent TB in populations with a high-burden of HIV infection.
\end{abstract}

Keywords: published literature, tuberculosis recurrence, HIV, Africa.

DOI:http:/ /dx.doi.org/10.4314/ahs.v15i4.24

Cite as: Moodley Y, Govender K. A systematic review of published literature describing factors associated with tuberculosis recurrence in people

living with HIV in Africa. Afri Health Sci. 2015;15(4):1239-46. bttp:/ / dx.doi.org/10.4314/abs.v15i4.24

\section{Introduction}

Tuberculosis (TB) is a global health problem, with the African population amongst the populations with the highest burden of TB disease. ${ }^{1}$ This appears to be related to the high burden of HIV on the African continent. Indeed, HIV infection substantially increases the risk of developing future TB disease. ${ }^{1}$ Therefore, even HIV-infected individuals with a previous history of TB who might have been cured or successfully completed their TB treatment might develop TB again during their lifetime. This "recurrent" TB infection might be due to 1) a newly acquired infection with Mycobacterium tuberculosis following prior successful treatment for active TB disease, or 2) activation of latent $\mathrm{M}$. tubercu-

\footnotetext{
Corresponding author:

Yoshan Moodley,

Nelson R. Mandela School of Medicine,

University of KwaZulu-Natal, Durban,

South Africa.

Email: moodleyyo@ukzn.ac.za
}

losis from a previous exposure which did not result in active TB disease, or 3) activation of latent M. tuberculosis which remained following treatment completion for a prior episode of active TB disease. ${ }^{2}$ Persons with HIV infection have a higher risk of recurrent TB disease. ${ }^{1}$ In addition, there is significant mortality from TB infection in HIV infected persons. ${ }^{3}$ It is therefore important to identify additional factors associated with recurrent TB in the HIV-infected population to aid in the development of efficient risk-reduction interventions. The aim of this study was to conduct a systematic review of the published literature in order to identify additional risk factors for recurrent $\mathrm{TB}$ infection in people living with HIV/AIDS in Africa.

\section{Methods}

A formally registered protocol for this systematic review is unavailable. Briefly, we conducted a parallel search of PubMed and The WHO Global Library. In PubMed we searched using a combination of phrases/keywords and using a set of relevant MeSH terms (Table 1). 
Table 1. Electronic search strategy

\begin{tabular}{|c|c|c|c|}
\hline Database & Query & Search Terms & $\begin{array}{l}\text { Number of } \\
\text { Returned }\end{array}$ \\
\hline \multirow[t]{13}{*}{ PubMed } & 1 & Recurrence [MeSH Terms] & 150497 \\
\hline & 2 & Tuberculosis[MeSH Terms] & 162792 \\
\hline & 3 & HIV [MeSH Terms] & 83568 \\
\hline & 4 & Risk Factors [MeSH Terms] & 592615 \\
\hline & 5 & Africa $[\mathrm{MeSH}$ Terms] & 191475 \\
\hline & 6 & $\begin{array}{l}\text { (((Recurrent) OR Recurrence) OR } \\
\text { Recurring) OR Relapse [All Fields] }\end{array}$ & 560062 \\
\hline & 7 & Tuberculosis [All Fields] & 219757 \\
\hline & 8 & HIV [All Fields] & 287733 \\
\hline & 9 & $\begin{array}{l}\text { (Risk Factors) OR Predictors [All } \\
\text { Fields] }\end{array}$ & 1024743 \\
\hline & 10 & Africa [All Fields] & 249634 \\
\hline & 11 & $\begin{array}{l}((((\text { Query \#1) AND Query \#2) AND } \\
\text { Query \#3) AND Query \#4) } \\
\text { AND Query \#5 }\end{array}$ & 5 \\
\hline & 12 & $\begin{array}{l}((((\text { Query \#6) AND Query \#7) AND } \\
\text { Query \#8) AND Query \#9) } \\
\text { AND Query \#10 }\end{array}$ & 51 \\
\hline & 13 & (Query \#11) OR Query \#12 & 51 \\
\hline $\begin{array}{l}\text { WHO } \\
\text { Global } \\
\text { Health } \\
\text { Library }\end{array}$ & 1 & $\begin{array}{l}\text { (Recurrence [MeSH Terms]) AND } \\
\text { (Tuberculosis [MeSH Terms]) AND } \\
\text { (HIV [MeSH Terms]) } \\
\text { AND (Risk Factors [MeSH Terms]) } \\
\text { AND } \\
\text { (Africa [MeSH Terms]) }\end{array}$ & 12 \\
\hline
\end{tabular}

We had chosen to search PubMed with both these options to improve the sensitivity of the search. In addition to the PubMed literature search, we also performed a search of literature in the World Health Organisation's (WHO) Global Medical Library using the same MeSH terms used in the PubMed search. We were unable to search EMBASE as our institution does not have access to the database. Abstracts of studies identified from the literature search were screened using the inclusion and exclusion criteria specified in Table 2.

Table 2. Inclusion and exclusion criteria for this systematic review

\begin{tabular}{|l|l|}
\hline Inclusion Criteria & Exclusion Criteria \\
\hline $\begin{array}{l}\text { Original manuscripts published in English in } \\
\text { peer reviewed journals }\end{array}$ & $\begin{array}{l}\text { Unpublished data, review manuscripts, case } \\
\text { reports, commentaries, non-English manuscripts }\end{array}$ \\
\hline Research conducted in Africa & Research conducted outside Africa \\
\hline $\begin{array}{l}\text { Studies reporting risk factors for recurrent TB in } \\
\text { people living with HIV/AIDS }\end{array}$ & $\begin{array}{l}\text { Studies which do not report risk factors for } \\
\text { recurrent TB in people living with HIV/AIDS }\end{array}$ \\
\hline Studies conducted in the general population & $\begin{array}{l}\text { Research which does not involve the general } \\
\text { population or focusses on specific population } \\
\text { groups (For example, miners) }\end{array}$ \\
\hline Research in adults & Research in children \\
\hline
\end{tabular}

The reference lists of included manuscripts were also hand searched for relevant studies which might not have been identified during the literature search. The quality of included studies was evaluated using the 
Newcastle-Ottawa Scale. We did not extend our search to "grey area" literature. Our decision to exclude data from "grey area" literature might have introduced publication bias, however the "grey area" literature is often not peer reviewed and in the case of conference abstracts, may not have provided enough information to be included in the review. Two authors independently screened the articles for inclusion in the review, and the opinion of an expert would be sought in the event of a dispute.

Manuscripts describing findings from HIV-positive populations (either studies solely of HIV-infected populations, or studies which stratified results by HIV status) were reviewed and the relevant data abstracted where possible. In addition to key risk factors for recurrent TB in HIV-infected individuals, the following data elements were extracted from all included manuscripts: Author, country where the study was conducted and year of publication; study design; size of HIV infected population; incidence of recurrent TB; \% of cohort which was female; age; and CD4 count summary. Risk factors obtained from each study are primarily presented as a narrative. The characteristics of included studies are presented as descriptive statistics.

Figure 1. Flow chart showing study selection

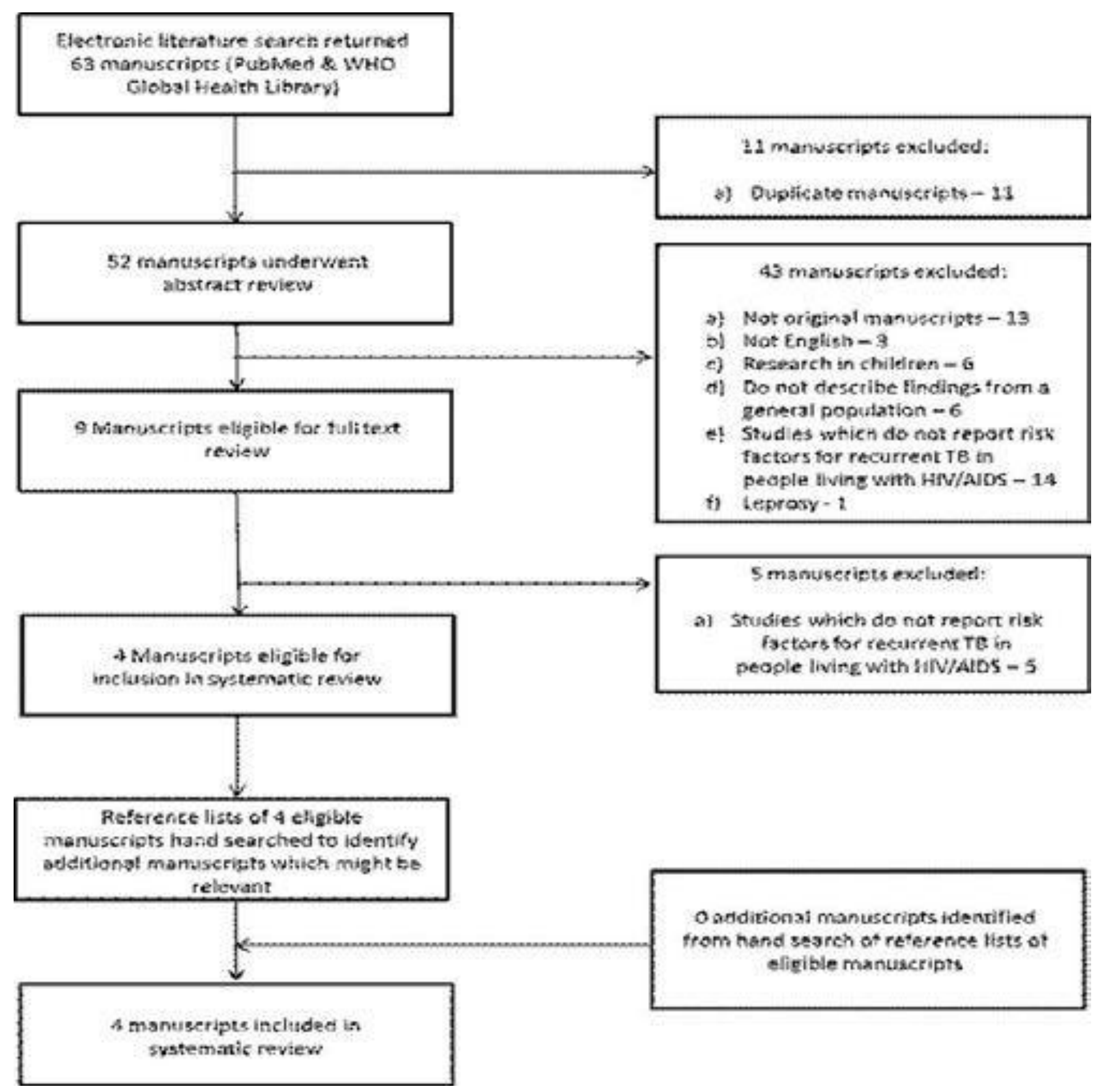




\section{Results}

The results of our literature search of the two databases are illustrated in Figure 1.

Our search yielded a total of 63 manuscripts. A total of 11 of these manuscripts were duplicates. Following review of the abstracts of the remaining 52 unique manuscripts, ${ }^{4-55} 9$ manuscripts ${ }^{7,15,18,23,25,26,31,33,35}$ were selected to undergo full text review. Reasons for exclusion of 43 manuscripts included: Not original manuscripts - 13 manuscripts; $6,8,10,16,29,32,38,39,42,46,49,50,53 \quad$ Not English - 3 manuscripts; ${ }^{30,40,45}$ Research in children - 6 manuscripts; $;$,12,17,27,47,48 Do not describe findings from a general population - 6 manuscripts; ${ }^{5,14,21,37,41,51}$ Studies which do not report risk factors for recurrent
TB in people living with HIV/AIDS - 14 manuscrip ts. ${ }^{9,11,13,19,20,22,24,28,36,43,44,52,54,55}$ In addition there was one manuscript which reported on leprosy. ${ }^{34}$

Following full text screening of the 9 manuscrip ts, ${ }^{7,15,18,23,25,26,31,33,35}$ there were 5 manuscripts which were found not to specifically report risk factors for recurrent TB in people living with HIV/AIDS. $75,26,33,35$ In addition, we screened the reference lists of the remaining 4 manuscripts ${ }^{18,23,25,31}$ in order to identify other potentially eligible studies for inclusion in our systematic review, which did not yield any additional manuscripts. Therefore, this systematic review was comprised of 4 eligible manuscripts. ${ }^{18,23,25,31}$

A description of all eligible manuscripts evaluated in this systematic review is shown in Table 3 .

Table 3. Characteristics of studies included in this systematic review

\begin{tabular}{|c|c|c|c|c|c|c|c|c|}
\hline $\begin{array}{l}\text { Authors } \\
\text { (Country, Year) }\end{array}$ & Study Design & $\begin{array}{l}\text { Total sample size } \\
\text { analyzed (HIV- } \\
\text { positives only) }\end{array}$ & $\begin{array}{lc}\text { Incidence } & \text { of } \\
\text { recurrent } & \text { TB } \\
(/ 100 \text { py }) & \end{array}$ & $\%$ Female & Median Age & \begin{tabular}{l|} 
Median \\
CD4+ count \\
(Range)
\end{tabular} & $\begin{array}{l}\text { Study } \\
\text { Quality } \\
\text { (Newcastle- } \\
\text { Ottawa Scale } \\
\text { Score) }\end{array}$ & $\begin{array}{l}\text { Potential } \\
\text { bias }\end{array}$ \\
\hline $\begin{array}{l}\text { Lahey et al. } \\
\text { (Tanzania, 2013) }\end{array}$ & $\begin{array}{l}\text { Prospective } \\
\text { observational }\end{array}$ & 979 & $\begin{array}{l}\text { HIV-positive with } \\
\text { definite TB: } 4.57 \\
\text { HIV-positive with } \\
\text { definite/probable } \\
\text { TB: } 7.42\end{array}$ & 75.6 & $\begin{array}{l}\text { Median age } \\
\text { of HIV- } \\
\text { positive } \\
\text { patients with } \\
\text { prior history } \\
\text { of TB: } 36.4 \\
\text { years }\end{array}$ & \begin{tabular}{l}
\multicolumn{3}{l}{ HIV-positive } \\
patients \\
a prith \\
a prior history \\
of $\quad$ TB: $\quad 347$ \\
$\left(\begin{array}{lr}262- & 549\end{array}\right)$ \\
cells $/ \mu \mathrm{L}$
\end{tabular} & 7 & $\begin{array}{l}\text { Selection, } \\
\text { performance }\end{array}$ \\
\hline $\begin{array}{l}\text { Houben et al. } \\
\text { (Malawi, 2012) }\end{array}$ & $\begin{array}{l}\begin{array}{l}\text { Prospective } \\
\text { observational }\end{array}\end{array}$ & 623 & $\begin{array}{l}\text { HIV-positive not } \\
\text { on ART: } 3.9 \\
\text { HIV-positive on } \\
\text { ART: } 3.0\end{array}$ & 53.7 & $\begin{array}{l}\text { No } \\
\mathrm{t} \\
\text { specified. } \\
50.6 \% \quad \text { of } \\
\text { cohort }<35\end{array}$ & Not specified & 8 & Performance \\
\hline $\begin{array}{l}\text { Isanaka et al. } \\
\text { (Tanzania, 2012) }\end{array}$ & $\begin{array}{l}\text { Sub-analysis } \\
\text { of randomized } \\
\text { controlled trial } \\
\text { data }\end{array}$ & Unclear & $\begin{array}{l}12 \text { events/644 } \\
\text { person months } \\
\text { and } 11 \text { events/704 } \\
\text { person months in } \\
\text { HIV-infected } \\
\text { persons with non- } \\
\text { iron deficiency } \\
\text { anaemia and iron } \\
\text { deficiency } \\
\text { anaemia, } \\
\text { respectively. }\end{array}$ & Unclear & Unclear & Unclear & 8 & $\begin{array}{l}\text { Selection, } \\
\text { performance }\end{array}$ \\
\hline $\begin{array}{l}\text { Hawken et al. } \\
\text { (Kenya, 1993) }\end{array}$ & $\begin{array}{l}\text { Prospective } \\
\text { observational }\end{array}$ & 58 & $\begin{array}{l}\text { In patients with } \\
\text { HIV-infection: } \\
16.7\end{array}$ & $38.0 \%$ & $\begin{array}{l}\text { Not reported. } \\
65 \% \text { of } \\
\text { patients }<35 \\
\text { years old. }\end{array}$ & Not reported & 8 & Selection \\
\hline
\end{tabular}


Risk factors for recurrent $\mathrm{TB}$ in people living with HIV/AIDS were evaluated in participants from 4 studies conducted in 3 countries in Africa (Kenya, Malawi and Tanzania). ${ }^{18,23,25,31}$ Three of the eligible manuscripts describe prospective observational studies. ${ }^{18,23,31}$ One manuscript described the secondary analysis of data obtained from a randomized controlled trial. ${ }^{25}$ Females comprised $38 \%{ }^{18} 54 \%{ }^{23}$ and $76 \%{ }^{31}$ of HIV-infected participants described in three of the eligible manuscripts. The remaining manuscript did not stratify results for gender by HIV status. ${ }^{25}$ The median age of HIV-infected participants in one manuscript was 36 years old. ${ }^{31}$ Although median age was not specified in two manuscripts, approximately half of the HIV-infected study population was $<35$ years old in one manuscript ${ }^{23}$ while this proportion was $65 \%$ in another manuscript. ${ }^{18}$ The remaining manuscript did not stratify results for age by HIV status. ${ }^{25}$ Median CD4 counts were reported in one of the 4 manuscripts only. ${ }^{31}$

There were several factors associated with a higher risk of developing recurrent TB infection identified in this systematic review. Risk factors for recurrent TB in people living with HIV/AIDS obtained from the full text review of eligible manuscripts are shown in Figure 2.

Figure 2. Factors associated with recurrent tuberculosis infection in persons living with HIV/AIDS in Africa

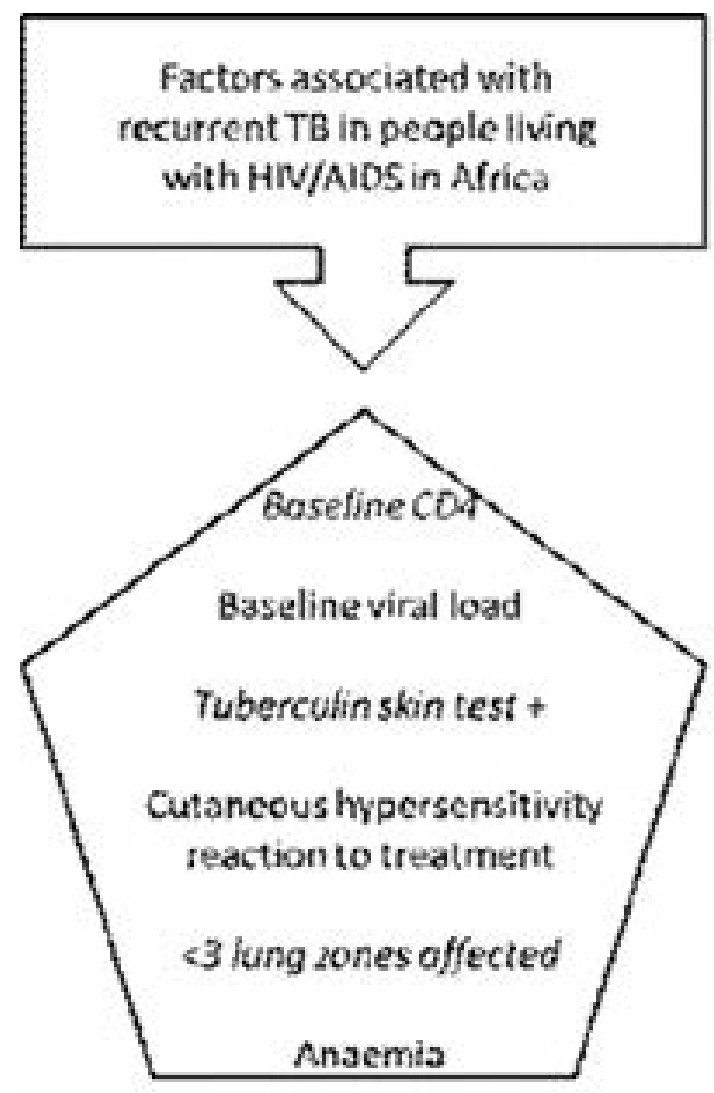

Most of these risk factors were identified from the study of Lahey et $\mathrm{al}^{31}$ and included: Baseline CD4 count, baseline HIV viral load, and a positive tuberculin skin test. Factors which were not associated with a higher risk of recurrent TB in HIV-infected individuals reported in the study of Lahey et al, ${ }^{31}$ included ART status and age. In their study, Houben and colleagues conducted a sub-analysis of HIV-infected individuals but only investigated whether ART status was associated with recurrent TB infection in this population. ${ }^{23}$ As

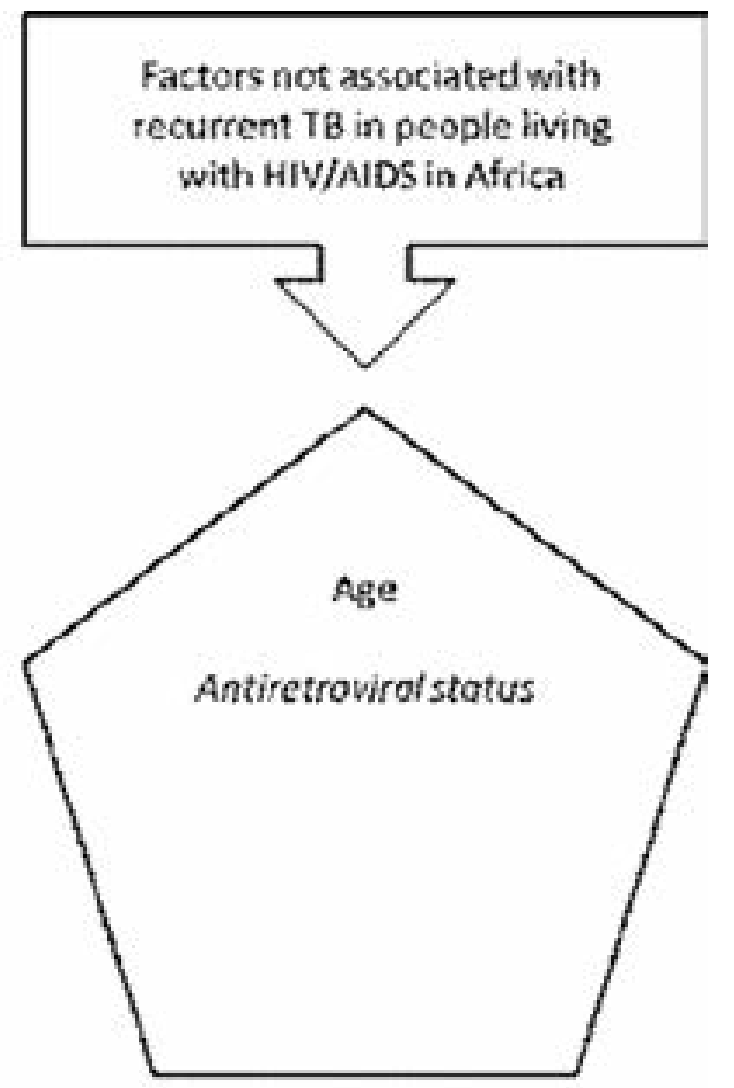

with the study of Lahey et $a 1,{ }^{31}$ the study of Houben and colleagues did not identify an association between ART status and recurrent TB in HIV-infected individuals. ${ }^{23}$ In the study conducted by Hawken and colleagues, there were two factors associated with a higher risk of recurrent TB in HIV-infected patients who had completed treatment: cutaneous hypersensitivity reaction to treatment and $<3$ lung zones affected by prior TB disease. $^{18}$ Isanaka et al., found that anaemia with or without iron-deficiency was associated with a 4- to 7-fold 
increased risk of recurrent tuberculosis in HIV-infected patients when potential confounders were accounted for. ${ }^{25}$

\section{Discussion}

Despite the high burden of HIV-TB co-infection on the African continent, there appears to be very little published peer-reviewed literature related to identifying risk factors for recurrent TB in HIV-infected individuals emanating from Africa. It is possible that the complexity of sharing data between TB and HIV programs (which have traditionally been vertical programs at African health care facilities), ${ }^{56}$ makes research relat- ed to HIV-TB co-infection very difficult. Therefore it is likely that collaborative activities between HIV and TB health services which have been shown to improve patient outcomes ${ }^{57}$ might also improve research efforts as a consequence.

The risk factors for recurrent TB in HIV-infected individuals identified in this systematic review were essentially extracted from four manuscripts ${ }^{18,23,25,31}$ and included baseline CD4 count, baseline HIV viral load, a positive tuberculin skin test, cutaneous hypersensitivity reaction to treatment, having $<3$ lung zones affected by prior TB disease, and anaemia. The findings of this systematic review have identified a gap in the current literature and highlight the important role of future clinical studies studying recurrent TB in the HIV-infected population. Due to the insufficient number of published manuscripts identified during the literature search, we were unable to perform a meta-analysis which could have provided pooled risk estimates for risk factors associated with recurrent TB in $\mathrm{HIV}$-infected individuals in Africa. This further highlights the need for more research initiatives aimed at identifying risk factors for recurrent TB in HIV-infected individuals living in Africa, and further efforts to disseminate the findings of these studies through peer-reviewed manuscripts to the wider scientific community. This systematic review was also unable to provide information related to the stratification of recurrent TB into re-infection with $\mathrm{M}$. tuberculosis or TB relapse. Before risk factors can be identified for these pathways leading to recurrent TB disease, adequately-powered genetic studies in African populations are required to accurately determine the burden of re-infection with $\mathrm{M}$. tuberculosis and TB relapse.
Unfortunately, the lack of studies describing recurrent TB in Africa which stratify results by HIV-status is a hindrance to understanding risk factors for recurrent TB in this population. It is possible that implementing guidelines related to the publishing of observational studies in peer-reviewed medical journals reporting recurrent TB in populations with a high-burden of HIV infection might be a worthwhile approach to generating higher-level evidence for risk factors for recurrent TB in the form of systematic reviews and meta-analyses.

\section{Acknowledgment}

This work was supported through postdoctoral funding awarded by the South African National Research Foundation. The funding source played no role in designing the study; in the collection, analysis, and interpretation of data; in writing the report; or in the decision to sub- mit this article for publication. The authors declare that there are no conflicts of interest.

\section{References}

1. Corbett EL, Marston B, Churchyard GJ, De Cock KM. Tuberculosis in sub-Saharan Africa: opportunities, challenges, and change in the era of antiretroviral treatment. Lancet. 2006; 367:926-937. doi: 10.1016/S01406736(06)68383-9

2. Millet JP, Shaw E, Orcau A, Casals M, Miro JM, Cayla JA. Tuberculosis recurrence after completion treatment in a European city: reinfection or relapse? PLoS One. 2013; 8:e64898. doi: 10.1371/journal.pone.0064898

3. Mukadi YD, Maher D, Harries A. Tuberculosis case fatality rates in high HIV prevalence populations in sub-Saharan Africa. Aids. 2001; 15:143-152.

4. Bellamy R, Ruwende C, McAdam KP, et al. Mannose binding protein deficiency is not associated with malar- ia, hepatitis B carriage nor tuberculosis in Africans. Qjm.

1998; 91:13-18. doi: 10.1093/qjmed/91.1.13

5. Charalambous S, Grant AD, Moloi V, et al. Contribution of reinfection to recurrent tuberculosis in South African gold miners. Int J Tuberr Lung Dis. 2008; 12:942948.

6. Crampin AC, Glynn JR, Fine PE. What has Karonga taught us? Tuberculosis studied over three decades. Int $\mathrm{J}$ Tuber Lung Dis. 2009; 13:153-164.

7. Crampin AC, Mwaungulu JN, Mwaungulu FD, et al. Recurrent TB: relapse or reinfection? The effect of HIV in a general population cohort in Malawi. Aids. 2010; 24:417-426. doi: 10.1097/QAD.0b013e32832f-51cf. 
8. Daley CL. Tuberculosis recurrence in Africa: true relapse or re-infection? Lancet. 1993; 342:756-757.

9. De Cock KM, Colebunders R, Francis H, et al. Evaluation of the WHO clinical case definition for AIDS in rural Zaire. Aids. 1988; 2:219-221.

10. Douglas JG, McLeod MJ. Pharmacokinetic factors in the modern drug treatment of tuberculosis. Clin Pharmacokinet. 1999; 37:127-146. doi: 10.2165/00003088-

199937020-00003

11. Feleke Y, Abdulkadir J, Aderaye G. Prevalence and clinical features of tuberculosis in Ethiopian diabetic patients. East Afr Med J. 1999; 76:361-364.

12. Ferrand RA, Luethy R, Bwakura F, Mujuru H, Mill- er RF, Corbett EL. HIV infection presenting in old- er children and adolescents: a case series from Hara- re, Zimbabwe. Clin Infect Dis. 2007; 44:874-878. doi:

10.1086/511878

13. Glynn JR, Warndorff DK, Fine PE, Munthali MM, Sichone W, Ponnighaus JM. Measurement and determinants of tuberculosis outcome in Karonga District, Malawi. Bull World Health Organ. 1998; 76:295-305.

14. Grant AD, Charalambous S, Fielding KL, et al. Effect of routine isoniazid preventive therapy on tuberculosis incidence among HIV-infected men in South Africa: a novel randomized incremental recruitment study. JAMA. 2005; 293:2719-2725. doi: 10.1001/ jama.293.22.2719.

15. Gupta A, Wood R, Kaplan R, Bekker LG, Lawn SD. Tuberculosis incidence rates during 8 years of follow-up of an antiretroviral treatment cohort in South Africa: comparison with rates in the community. PLoS One. 2012; 7:e34156. doi: 10.1371/journal.pone.0034156

16. Harries AD, Hargreaves NJ, Salaniponi FM. Design of regimens for treating tuberculosis in patients with HIV infection, with particular reference to sub-Saharan Africa. Int J Tuber Lung Dis. 2001; 5:1109-1115.

17. Hashim MS, Salih MA, el Hag AA, et al. AIDS and HIV infection in Sudanese children: a clinical and epidemiological study. AIDS Patient Care STDS. 1997; 11:331-337.

18. Hawken M, Nunn P, Gathua S, et al. Increased recurrence of tuberculosis in HIV-1-infected patients in Kenya. Lancet. 1993; 342:332-337.

19. Hesseling AC, Walzl G, Enarson DA, et al. Baseline sputum time to detection predicts month two culture conversion and relapse in non-HIV-infected patients. Int J Tuber Lung Dis. 2010; 14:560-570.

20. Hira SK, Ngandu N, Wadhawan D, et al. Clinical and epidemiological features of HIV infection at a referral clinic in Zambia. J Acquir Immune Defic Syndr. 1990; 3:87-91.
21. Hnizdo E, Singh T, Churchyard G. Chronic pulmonary function impairment caused by initial and recurrent pulmonary tuberculosis following treatment. Thorax. 2000; 55:32-38. doi: 10.1136/thorax.55.1.32

22. Houben RM, Glynn JR, Mallard K, et al. Human immunodeficiency virus increases the risk of tuberculosis due to recent re-infection in individuals with latent infection. Int J Tuberc Lung Dis. 2010; 14:909-915.

23. Houben RM, Glynn JR, Mboma S, et al. The impact of HIV and ART on recurrent tuberculosis in a sub-Saharan setting. Aids. 2012; 26:2233-2239. doi: 10.1097/ QAD.0b013e32835958ed

24. Ipuge YA, Rieder HL, Enarson DA. Adverse cutaneous reactions to thiacetazone for tuberculosis treatment in Tanzania. Lancet. 1995; 346:657-660. doi: 10.1016/ S0140-6736(95) 92278-4

25. Isanaka S, Mugusi F, Urassa W, et al. Iron deficien- cy and anemia predict mortality in patients with tuberculosis. J Nutr. 2012; 142:350-357. doi: 10.3945/ jn.111.144287

26. Johnson JL, Okwera A, Vjecha MJ, et al. Risk factors for relapse in human immunodeficiency virus type 1 infected adults with pulmonary tuberculosis. Int J Tu-berc Lung Dis. 1997; 1:446-453.

27. Kabangila R, Semvua K, Rambau P, et al. Pulmonary histoplasmosis presenting as chronic productive cough, fever, and massive unilateral consolidation in a 15 -yearold immune-competent boy: a case report. J Med Case Rep. 2011; 5:374. doi: 10.1186/1752-1947-5-374

28. Kelly PM, Cumming RG, Kaldor JM. HIV and tuberculosis in rural sub-Saharan Africa: acohort study with two year follow-up. Trans R Soc Trop Med Hyg. 1999;

93:287-293. doi: 10.1016/S0035-9203(99)90025-1

29. Kidenya BR, Webster LE, Behan S, et al. Epidemiology and genetic diversity of multidrug-resistant tuberculosis in East Africa. Tuberculosis (Edinb). 2014; 94:1-7. doi: 10.1016/j.tube.2013.08.009

30. Kornaszewski W, Kornaszewska M, Skotnicki AB. [Acquired immunodeficiency syndrome (AIDS) in the African environment]. Postepy Hig Med Dosw. 1986; 40:331-346.

31. Lahey T, Mackenzie T, Arbeit RD, et al. Recurrent tuberculosis risk among HIV-infected adults in Tanzania with prior active tuberculosis. Clin Infect Dis. 2013; 56:151-158. doi: $10.1093 / \mathrm{cid} / \mathrm{cis} 798$

32. Lawn SD, Myer L, Badri M, Bekker LG, Wood R. Reply to Ouattara et al.: past history of tuberculosis is not a risk factor for incident tuberculosis during antiretroviral treatment in South Africa. Aids. 2007; 21:388389. doi: 10.1097/QAD.0b013e328011ec88 
33. Lawn SD, Myer L, Bekker LG, Wood R. Burden of tuberculosis in an antiretroviral treatment programme in sub-Saharan Africa: impact on treatment outcomes and implications for tuberculosis control. Aids. 2006; 20:1605-1612. doi: 10.1097/01.aids.0000238406.93249. cd 34. Lienhardt C, Kamate B, Jamet P, et al. Effect of HIV infection on leprosy: a three-year survey in Bamako, Mali. Int J Lepr Other Mycobact Dis. 1996; 64:383-391.

35. Luzze H, Johnson DF, Dickman K, et al. Relapse more common than reinfection in recurrent tuberculosis 1-2 years post treatment in urban Uganda. Int J Tuber Lung Dis. 2013; 17:361-367. doi: 10.5588/ijtld.11.0692

36. Malkin JE, Prazuck T, Simonnet F, et al. Tuberculosis and human immunodeficiency virus infection in west Burkina Faso: clinical presentation and clinical evolution. IntJ Tuberc Lung Dis. 1997; 1:68-74.

37. Mallory KF, Churchyard GJ, Kleinschmidt I, De Cock KM, Corbett EL. The impact of HIV infection on recurrence of tuberculosis in South African gold miners. Int J Tuberc Lung Dis. 2000; 4:455-462.

38. Marras TK, Daley CL. Epidemiology of human pulmonary infection with nontuberculous mycobacteria. Clin Chest Med. 2002; 23:553-567. doi: 10.1016/ S0272-5231(02)00019-9

39. Meintjes G, Rabie H, Wilkinson RJ, Cotton MF. Tuberculosis-associated immune reconstitution inflammatory syndrome and unmasking of tuberculosis by antiretroviral therapy. Clin Chest Med. 2009; 30:797-810, x. doi: 10.1016/j.ccm.2009.08.013

40. Muganga N, Nkuadiolandu A, Mashako LM. [Clinical manifestations of AIDS in children in Kinshasa]. Pediatrie. 1991; 46:825-829.

41. Murray J, Sonnenberg P, Shearer S, Godfrey-Faussett P. Drug-resistant pulmonary tuberculosis in a cohort of southern African goldminers with a high prevalence of HIV infection. S Afr Med J. 2000; 90:381-386.

42. Murray JF. Tuberculosis and HIV infection: global perspectives. Respirology. 1997; 2:209-213. doi: 10.1111/ j.1440-1843.1997.tb00081.x

43. Muture BN, Keraka MN, Kimuu PK, Kabiru EW, Ombeka VO, Oguya F. Factors associated with default from treatment among tuberculosis patients in Nairobi province, Kenya: a case control study. BMC Public Health. 2011; 11:696. doi: 10.1186/1471-2458-11-696

44. Nicholas S, Sabapathy K, Ferreyra C, Varaine F, Pujades-Rodriguez M. Incidence of tuberculosis in HIV-infected patients before and after starting combined antiretroviral therapy in 8 sub-Saharan African HIV programs. J Acquir Immune Defic Syndr. 2011;
57:311-318. doi: 10.1097/QAI.0b013e318218a713

45. Nicolas J. [AIDS in the African infant and child]. Med Mal Infect. 1990; 20:454-458.

46. Paul J. Royal Society of Tropical Medicine and Hygiene Meeting at Manson House, London, 12 December 1996. HIV and pneumococcal infection in Africa. Microbiological aspects. Trans R Soc Trop Med Hyg. 1997; 91:632-637.

47. Rekha B, Swaminathan S. Childhood tuberculosis - global epidemiology and the impact of HIV. Paediatr Respir Rev. 2007; 8:99-106. doi: 10.1016/j. prrv.2007.04.010

48. Schaaf HS, Krook S, Hollemans DW, Warren RM, Donald PR, Hesseling AC. Recurrent culture-confirmed tuberculosis in human immunodeficiency virus-infected children. Pediatr Infect Dis J. 2005; 24:685-691.

49. Scully C, Cawson RA, Porter SR. Acquired immune deficiency syndrome: review. BrDent J. 1986; 161:53-60.

50. Semba RD, Darnton-Hill I, de Pee S. Addressing tuberculosis in the context of malnutrition and HIV coinfection. Food Nutr Bull. 2010; 31:S345-364.

51. Sonnenberg P, Murray J, Glynn JR, Shearer S, Kambashi B, Godfrey-Faussett P. HIV-1 and recurrence, relapse, and reinfection of tuberculosis after cure: a cohort study in South African mineworkers. Lancet. 2001; 358:1687-1693. doi: 10.1016/S0140-6736(01)06712-5

52. Stein ME, Spencer D, Kantor A, Ruff P, Haim N, Bezwoda WR. Epidemic AIDS-related Kaposi's sarco$m a$ in southern Africa: experience at the Johannesburg General Hospital (1980-1990). Trans R Soc Trop Med Hyg. 1994; 88:434-436.

53. Warren RM, van Helden PD. HIV-1 and tuberculosis infection. Lancet. 2002; 359:1618-1619; author reply 1619-1620. doi: 10.1016/S0140-6736(02)08496-9

54. Whalen CC, Zalwango S, Chiunda A, et al. Secondary attack rate of tuberculosis in urban households in Kampala, Uganda. PLoS One. 2011; 6:e16137. doi:

10.1371/journal.pone.0016137

55. Wilkinson D, Pillay M, Davies GR, Sturm AW. Resistance to antituberculosis drugs in rural South Africa: rates, patterns, risks, and transmission dynamics. Trans $R$ Soc Trop Med Hyg. 1996; 90:692-695.

56. Gunneberg C, Reid A, Williams BG, Floyd K, Nunn P. Global monitoring of collaborative TB-HIV activi- ties. Int J Tuber Lung Dis. 2008; 12:2-7.

57. Howard AA, El-Sadr WM. Integration of tuberculosis and HIV services in sub-Saharan Africa: lessons learned. Clin Infect Dis. 2010; 50 Suppl 3:S238-244. doi:10.1086/651497 